\title{
Clinical Study of Influence of Prognostic Factors on the Outcome of Tympanoplasty Surgery
}

\author{
P. Hair krishna ${ }^{1}$, T. Sobha Devi ${ }^{2}$ \\ ${ }^{I}$ Department of E.N.T, S.V.Medical college, Tirupathi, NTRUHS, India \\ ${ }^{2}$ Department of Anatomy, S.V.Medical college, Tirupathi, NTRUHS, India
}

\begin{abstract}
Asbtract: Myringoplasty is the operation specifically designed to close tympanic membrane defects the main aim of surgery of chronic ear disease is to eliminate disease process and reconstruct middle ear to give the patient a dry safe and functioning ear. In this study a clinical study of myringoplasty underlay technique in the management of central perforations done. Main emphasis is laid on evaluation of prognostic factors like Eustachian tube function, middle ear mucosa at operation and audiometric evaluation pre and post operatively. A series of patients treated in the Department of ENT, Government General Hospital, Kurnool during the period of two years is taken for the study. Relevant literature regarding anatomy, physiology, pathophysiology, clinical features and various methods of medical and surgical management are reviewed.
\end{abstract}

Keywords : Chronic suppurative otitis media, Tympanoplasty, Eustachian tube function, middle ear mucosa, audiometric evaluation.

\section{Introduction}

Myringoplasty is the operation specifically designed to close tympanic membrane defects. A perforation in the tympanic membrane can result from physical injury, scalds, burns, pressure effects, head injuries or infection process; out of this suppurative process is the most common cause. Most of these perforations usually heal spontaneously. But this spontaneous healing is hampered by chronicity of infection and certain pathophysiological changes at the perforated margin, leading to a non healing permanent perfoation. It leads to constant exposure of middle ear for reinfection hearing disability and danger of certain intracranial and extracranial complications. The main aim of surgery of chronic ear disease is to eliminate disease process and reconstruct middle ear to give the patient a dry safe and functioning ear. In this journey towards the aim, the first milestone is reconstruction of tympanic membrane.In this study a clinical study of myringoplasty underlay technique in the management of central perforations done. Main emphasis is laid on evaluation of prognostic factors like Eustachian tube function, middle ear mucosa at operation and audiometric evaluation pre and post operatively. A series of patients treated in the Department of ENT, Government General Hospital, Kurnool during the period of two years is taken for the study. Relevant literature regarding anatomy, physiology, pathophysiology, clinical features and various methods of medical and surgical management are reviewed.

\section{Materials And Methods}

A prospective study was carried out at Dept.of ENT and HN Surgery KMC, Kurnool, as part of thesis submission, during period 2006-08. Fifty cases of CSOM with deafness aged between 15-45yrs age group and all cases with Middle ear risk index between 1to3, were taken up for type I Tympanoplasty, with temporalis fascia as graft material. Simple Mastoidectomy was done in cases where mucosa was found abnormal.

Exclusion criteria

1. Infection in nose sinuses, nasopharynx and oropharynx.

2. Deviated nasal septum enlarged inferior turbinate, polyp in the nose.

3. Sensorl neural hearing loss.

4. Atticoantral disease cholesteatoma.,

Preoperative evaluation

Duration of Otorrhea, duration of deafness, size of perforation, webers lateralization, Eustatian tube mucociliary clearance by dye test, status of middle ear mucosa pathology at operation, were assessed. Pre and post operative pure tone audiograms were taken to assess pure tone average hearing gain air bone gap closure. Postoperative follow up:-

Graft uptake was assessed by otoscopy at eight weeks postoperatively. Postoperative audio -grams were taken to assess the improvement in hearing.Patients are categorized for each variable, to be assessed and the base line data thus obtained is analyzed. The analyses of results obtained are represented in a tabular form. 
Tympanoplasty reporting protocol

Deafness grading_Mild $=21$ to $40 \mathrm{db}$ loss, Moderate $=41$ to $55 \mathrm{db}$ loss, Severe $=$ More than $55 \mathrm{db}$ loss,

1. Size of perforation :Large $=$ More than $50 \%$ of T.M surface area, Small $=$ Small than $50 \%$ of T.M surface area

2. Mucociliary clearance of Eustatian tube $:$ Abnormal $=$ dye not seen within $10 \mathrm{~min}$ Normal= dye seen within $10 \mathrm{~min}$

3. Middle Ear risk Index: Normal $=0$, Mild pathology $=1-3$, Moderate pathology $=4-6$, Severe pathology $=$ 7-12

4. Air bone gap closer Brackmann criterion: Excellent $=0-10 \mathrm{db}$, Good $=10-20 \mathrm{db}$, Fair $=20-30 \mathrm{dbPoor}=$ More than $30 \mathrm{db}$

Assessment of Eustachian tube function

Just prior to operation, Eustachian tubal function was tested by nasal endoscopy following instillation of 15 drops of fluorecein sodium dye (one in five dilution of $20 \%$ solution - sterile) into external auditory canal of the ear with perforated tympanic membrane. Cases in which, the dye was seen at nasopharyngeal end of tube within $10 \mathrm{~min}$ of its instillation into the ear were classified as having normal patent Eustachian tubes and others as having abnormal blocked eustatian tubes.

\section{Observations}

$64 \%$ of the patients presented with duration of Otorrhea for more than 5 yrs $86 \%$ of the patients presented with duration deafness for more than 5 yrs. $54 \%$ of the patients presented with age more than $25 \mathrm{yrs}$. $64 \%$ of the patients are females. $58 \%$ of the patients are mildly deaf $34 \%$ moderately deaf $8 \%$ were severely deaf. 58\% of the patients presented with small tympanic membrane perforation and $42 \%$ presented with large perforation. Eustachian tube mucociliary clearance assessed by dye test showed that the test is abnormal in 54\%. Middle Ear mucosa Pathology was assessed at operation and in 58\% of the cases it was found normal. Simple Mastoidectomy was done in cases showing abnormal middle Ear mucosa Pathology.Postoperatively graft uptake was assessed at 8 weeks and found that in $78 \%$ of the cases it is successful. Postoperative hearing evaluation by pure tone audiometry revealed that the serviceable hearing that is air bone gap closer achieved in $\mathrm{db}$ was $54 \%$ up to $10 \mathrm{db}$, up to15db $12 \%$, more than $30 \mathrm{db} 22 \%$. When Belfast rule of thumb (Gordon Smyth) was applied, postoperative air threshold gain or improvement by less than $30 \mathrm{db}$ was observed in $38 \%$ and more than $30 \mathrm{db}$ in $62 \%$ of patients. The average hearing gain in db observed in the study population is $7.7 \mathrm{db}$. The average air bone gap closure achieved in the study population is $9.75 \mathrm{db}$. Master chart showed the observations in patients in table no. 1

\section{Discussion}

Analysis of results showed in table no. 2. The present study was undertaken, 1) to evaluate patients undergoing type -I tympanoplasty for Chronic Suppurative Otitis Media with Deafness in terms of Graft uptake and Hearing gain or improvement , 2) to evaluate the relative incidence of the following factors viz., a) duration of otorrhea b)duration of deafness c) Eustachian Tube mucocilliary clearance function, d) Middle ear mucosa pathology at operation in patients undergoing Type -I Tympanoplasty 3)The surgical outcome measures and relative incidence of these factors will be compared with that of similar studies .The final objective in myringoplasty is to achieve a safe, dry ear, with an intact tympanic membrane .Most authors agree that preoperative abnormalities indicative of severity of underlying Eustachian tube dysfunction and Infection have a significant influence on prognosis . Black noted that good risk patients had a $67 \%$ chance of obtaining hearing within $10 \mathrm{db}$ versus only a $25 \%$ chance if they were considered poor risk.In the present study $54 \%$ of the patients are of more than $25 \mathrm{yrs}$ of age. $46 \%$ of them were in the age group of less than $25 \mathrm{yrs}$. where as in a study conducted by Ajmal (Ref.2) 66\% of the patients belonged to the age group of more than 25yrs and 33\% of them belonged to less than 25 years. The sex distribution in the present study showed $36 \%$ of males and $64 \%$ Females, where as Ajmal in Ref.2- Showed 58.4\% of males and 41.6 females, Saeed in Ref.24- Showed 59\% males 40.95 females.In the present study Eustachian tube mucocilliary function as assessed by fluorecein dye test showed abnormal patency in 54\% and normal in 46\% where as Sethi in Ref.26- Showed abnormal patency in $32 \%$ and normal in $68 \%$. Gimenz (Ref.9) showed abnormality in $22 \%$ and $50 \%$ normal patency. The present study showed abnormal middle ear mucosal pathology such as polyoidal mucosa, granulations, tympanosclerosis in $42 \%$ of patients and normal mucosa in 58\%. Whereas Debora in (Ref. 5) has shown 13.4 $\%$ of his patients showed middle ear mucosal pathology and normal mucosa in $81.4 \%$. Sethi in Ref 26- has shown $20 \%$ abnormal mucosa and $80 \%$ of them having normal mucosa. The present study showed that in $58 \%$ of patients there was small central perforation and in $42 \%$ large perforation was present. In the study done by Ajmal in Ref. 2- there were patients with small perforations in 33.3\% and 25\% large , Sethi in Ref. 26- 16\% were small perforations and 66\% were large Saeed in Ref.24- 66\% were large perforation, Debora in Ref.542.2\% were small perforations and $57.7 \%$ were large perforations. The present study showed successful graft 
uptake in $78 \%$ and failure of graft in $22 \%$ of patients. In the review literature various authors have reported the successful Graft uptake and closure rate as follows, viz., Ajmal in Ref.2- 60\% Debora in Ref.5- 80.4\%, Frade in Ref.6-73.6\%, Kageyama in Ref.14- 82\%, Kotecha in Ref. 15- 82.2\% Saeed in Ref.24- 73.2\%, Sheehy in Ref.25- 97\%, Sethi in Ref.26- 76\%, Yaor in Ref.28- as 89\%. In the present study Air-Bone Gap closure upto $10 \mathrm{db}$ was achieved in $54 \%$ and up to15db in $12 \%$ of patients. In a similar study by Yaor in Ref.28- reported air bone gap closure to $10 \mathrm{db}$ in $40.5 \%$ of patients and upto $15 \mathrm{db}$ closure in $2.7 \%$, Dr.Mahadevaiah Ref.17- reported $10 \mathrm{db}$ closure in $26 \%$ and upto $15 \mathrm{db}$ closure in $32 \%$ of his patients. In the present study the average hearing gain observed among study population is 7.7db. Whereas Pala \& Ramsay in Ref.19- reported 8.0db in their studies. This is in coincidence with the above authors. In the present study, when Belfast rule of thumb (Gordon Smyth) was applied post-operative air threshold gain or improvement in hearing was less than $30 \mathrm{db}$ in $38 \%$ and more than $30 \mathrm{db}$ was observed in $62 \%$.From the above discussion it is apparent that even though the middle ear mucosa was normal only in 58\% of patients when compared to similar studies by Debora (81.4\%) Sethi (80\%), the successful graft uptake observed in the present study is $78 \%$ when compared to Graft uptake by Debora $(80.4 \%)$ and by Sethi $(76 \%)$. Thus uniform data may not be obtained in all of the variables studied because of observer variation in various studies. The variables are analyzed separately by various authors but in clinical practice all these factors are interconnected and act concomitantly in disease morbidity.

\section{Conclusions}

Chronic suppurative Otitis media still remains a important health problem in the society. The incidence of chronic suppurative Otitis media, $29.7 \%$ in the general populations shows the demand for the availability of medical services. The incidence of reporting of the disease is more common in the females and willingness to undergo surgery is also found more common in them. It may be because of the improved social interaction of females in the present day situations. It is represented in the present study that is 64\%.Tubotympanic type of CSOM is more common than the Attico-antral type (5.7\%). This is evident in the present study.Thorough clinical examination, history taking and the requirement of the patient in relation to hearing impairment is mandatory to plan the surgery. It is also necessary to have audiological evaluation for both prognostic evaluation and medico-legal aspect.The condition of the middle ear mucosa determines the outcome of the surgery. It also helps in predicting post-operative hearing gain.Patent Eustachian tube is required in tympanoplasty. Patency test like flurecin dye instillation is a simple and effective method of assessing the mucociliary clearance function of the E.T. tube.Cortical Mastoidectomy in those patients who have a middle ear disease in the form of hypertrophy, mucosal edema and granulations helps in clearing the auditus and disease from the mastoid air cells, which is a pre-requisite of a successful Tympanoplasty.Postoperative audiological evaluation after 8 weeks showed hearing gain of $7.7 \mathrm{~dB}$ on the average is similar to studies compared in the literature.Serviceable hearing that is air bone gap closure to less than $10 \mathrm{~dB}$ was achieved in majority of the patients (54\%). Long term follow-up for more than 2 years is prescribed to declare the successful tympanoplasty and serviceable hearing, which was not possible in this study. The study has made an attempt to show that careful selection of patients might play a role in obtaining better results, in terms of graft uptake or closure rate and also in interpreting hearing gain results after Tympanoplasty, as well as good technical expertise.

\section{References}

[1]. Ars B, Miled I, Ars. P.Allograft Myringoplasty. Acta Oto-Rhino Laryngologica Belgica 1995; 49: $207-18$

[2]. Ajmhal Hussain, Jrnl of P.G Med Inst Peshawar 2004 vol 18,no-4 Pg 695-698

[3]. Browning G.G. Medical Management of Chronic mucosal otitis media. Clinical Otoloryngology 1983; 9:141-4.

[4]. Browning G.G. The unsafeness of 'safe' ears. Journal of Laryngology and otology 1984; 98: 23-6.

[5]. Debora,Internationl Archives of otorhinolaryngology 2006 vol 10,no-4 Oct/Dec-3 ${ }^{\circ}$.

[6]. Frade Gonzalez C,Acta Otorhinolaringol Esp2002 Dec; 53(10):729-35.

[7]. Grippaudo M.Histopathological study of the ossicles in chronic otitis media. Journal of Laryngology and otology 1958: 72: 177-189.

[8]. Grote J.J. Biomaterials in Otology. Proceedings of the first International Symposium, 1983. Leiden, The Netherlands; martinus Nijhoff Publishers.

[9]. Gimenz, AlgarraJrnl of Laryngol,Otol1993 Oct;107(10):895-7.

[10]. Hough J.V.D. Experience in tympanoplasty - avoiding revisions and complications. Otolaryngologic clinics of North America 1982; 15:845-860.

[11]. Jackler RK, Schindler R.A. Myringoplasty with simple mastoidectomy results in eighty two consecutive patients. Otolaryngology and Head and Neck Surgery 1983; 91:14-17.

[12]. Jahn AF. Chronic otitis media: diagnosis and treatment. Medical clinics of North America 1991; 75: $1277-91$.

[13]. Karma P, Jokipii L, Ojala K, Jokipii AMM. Bacteriology of the chronically discharging middle ear. Acta Otolaryngologica (stakholm) 1978; 86: 110-14.

[14]. Kageyama Escobar GacMed Mex 2001,137(3):209-20;

[15]. Kotecha Clin Otolaryngol 1999, 24(2):126-9.

[16]. Lee. P.Kelly, G.Mills R.P. Clinical oto laryngology \& Allied sciences 2002; 27:331-4.

[17]. Mahadevaiah.Chronic suppurative Otitis media Management

[18]. Paparella M.M, Morizono T, Le. CT, Mancini F, Sipilla P.Choo Y.B. Sensorineural hearing loss in otitis media. Annals of Otology Rhinology and Laryngology 1984; 93: 623-9. 
[19]. Palva, Ramsay Clin otolaryngol 1995;20:329-35.

[20]. Rivas Lacarte MP, Casain T, Alonso A.Effects of Sodium hyaluronate on tympanic membrane perforations. Journal of International Medical Research 1992; 20: 353-9.

[21]. Rupa V, Raman R. Chronic Suppurative otitis media: Complicated Versus uncomplicated disease. Octa Otolaryngologia (Stackholm) $1991 ; 111: 530-5$.

[22]. SMYTH G.D.L. Outline of surgical management in chronic ear disease. Otolaryngologic clinics of North America. 1972a; 5:59-77.

[23]. SMYTH G.D.L. tympanic Reconstruction. Otolaryngologic clinics of North America 1972b; 5:111-125.

[24]. Saeed Al Ghamdi Ann.Saudi Med 1994;14(6):483-485.

[25]. Sheehy Ann Otol Rhinol Laryngol. 1980,89(4 pt1):331-4.

[26]. Sethi, Singh IJOHNS 2005, vol 57, Is 4, Pg 283-286.

[27]. Vartianen E. Findings in revision myringoplasty. Ear nose and throat Journal 1993; 72:201-4.

[28]. Yaor, Elkholy Ann.African Medicine 2006, vol 5, no 1, Pg 24-27.

\section{Textbooks}

1. Scott-Brown's Otolaryngology, Seventh Edition, 2008 by Alan G.Kerr.

2. Diseases of the Ear; Sixth edition 2006 Edited by Harold Ludman and Tony Wright

3. Logan Turner's Diseases of the Nose, Throat and Ear. Tenth Edition 1988, Edited by A.G.D. Maran.

4. Operative Surgery - Ear, Third Edition 1978 Edited by John Ballantyne.

5. Surgery of the Ear - Fifth edition 2001, Edited by Michael E. Glasscock III and George E.Shambaugh Jr

TABLE No. 1: MASTER CHART

\begin{tabular}{|c|c|c|c|c|c|c|c|c|c|c|c|c|c|c|c|c|c|c|}
\hline \multirow{2}{*}{$\begin{array}{l}\text { SL. } \\
\text { No }\end{array}$} & \multirow{2}{*}{$\begin{array}{l}\text { Ser/ } \\
\text { Age }\end{array}$} & \multirow[b]{2}{*}{ I.P.No. } & \multirow[b]{2}{*}{ DOA } & \multirow[b]{2}{*}{ Dos } & \multirow{2}{*}{$\begin{array}{l}\text { Otorhea } \\
\text { duration }\end{array}$} & \multirow{2}{*}{$\begin{array}{l}\text { Deafness } \\
\text { Duration }\end{array}$} & \multicolumn{2}{|c|}{ Size of perforation } & \multirow{2}{*}{$\begin{array}{c}\text { Webers } \\
\text { Lateralisa } \\
\text { tion }\end{array}$} & \multirow{2}{*}{$\begin{array}{c}\text { Eustatian } \\
\text { tube } \\
\text { function } \\
\text { Dyetest }\end{array}$} & \multirow{2}{*}{$\begin{array}{l}\text { Middle Ear } \\
\text { Mucosa }\end{array}$} & \multirow{2}{*}{$\begin{array}{c}\text { Graft } \\
\text { uptake }\end{array}$} & \multirow{2}{*}{\begin{tabular}{c|} 
Heari \\
ng \\
Gain \\
in \\
decibe \\
ls \\
\end{tabular}} & \multirow{2}{*}{$\begin{array}{c}\text { Air bone gap in } \\
\text { db }\end{array}$} & \multirow{2}{*}{$\begin{array}{c}\text { Air bone gap } \\
\text { closure } \\
\text { achived db }\end{array}$} & \multirow{2}{*}{$\begin{array}{c}\text { Preop } \\
\text { pure } \\
\text { tone } \\
\text { average } \\
\text { in db }\end{array}$} & \multirow{2}{*}{$\begin{array}{l}\text { Post op- } \\
\text { pure tone } \\
\text { average db }\end{array}$} & \multirow{2}{*}{$\begin{array}{c}\text { Belfast } \\
\text { rule of } \\
\text { thumb Air } \\
\text { threshold } \\
\text { db }\end{array}$} \\
\hline & & & & & & & $\begin{array}{l}\text { Large } \\
\text { Small }\end{array}$ & Side & & & & & & & & & & \\
\hline 1 & M-30 & 39404 & 10:3/32007 & $10 / 42007$ & 5 Years & 3 Years & Small & Right Ear & Leff Ear & Abromal & Nomal & Good & 6.7 & $\begin{array}{l}\text { Pre OP: } 20 \\
\text { Post OP: } 10\end{array}$ & 10.0 & 40.0 & 33.3 & $>30$ \\
\hline 2 & $F-26$ & 39462 & 10:3/2007 & 10,9:2007 & 5 Years & 2 Yasrs & Small & Right Ear & Right Ear & Abnomal & Polypoidal & Good & 8.4 & $\begin{array}{l}\text { Pre OP: } 20 \\
\text { Post OP: } 10\end{array}$ & 10.0 & 40.0 & 31.6 & $>30$ \\
\hline 3 & $F-27$ & 40183 & $10 / 82007$ & 10:11/2007 & 7 Years & 5 Years & Small & Right Ear & Right Ear & Abromal & Nomal & Good & 10.0 & $\begin{array}{l}\text { Pre OP: } 20 \\
\text { Post OP: } 10\end{array}$ & 10.0 & 33.3 & 25.0 & $<30$ \\
\hline 4 & F-27 & 41211 & 10/15/2007 & 10:16/2004 & 5 Years & 2 Years & Small & Leff Ear & Leff Ear & Nomal & Normal & Good & 8.5 & $\begin{array}{l}\text { Pre OP: } 20 \\
\text { Post OP: } 10\end{array}$ & 10.0 & 33.3 & 25.0 & $<30$ \\
\hline 5 & $\mathrm{~F}-20$ & 42217 & $10 / 2222007$ & $10 / 23 / 2007$ & 10 Yars & 10 Years & Large & Leff Ear & Left Esr & Abromal & Normal & Good & 8.3 & $\begin{array}{l}\text { Pre OP: } 20 \\
\text { Post OP: } 10 \\
\end{array}$ & 10.0 & 36.6 & 28.3 & $<30$ \\
\hline 6 & $\mathrm{~F}-21$ & 42223 & $10 / 2222007$ & $10 / 25 / 2007$ & 5 Years & 2 Years & Small & Left Ear & Left Ear & Nomal & Nomal & Good & 8.3 & $\begin{array}{l}\text { Pre op: } 20 \\
\text { Post Op:10 }\end{array}$ & 10.0 & 31.6 & 23.3 & $<30$ \\
\hline 7 & F-30 & 42255 & 10,2222007 & 10:25/2007 & 10 Years & 5 Years & $\begin{array}{l}\text { Lorge \& } \\
\text { Biliteral }\end{array}$ & Leff Ear & Left Ear & Abnomal & Granulations & Failure & 0.0 & $\begin{array}{l}\text { Pre OP: } 20 \\
\text { Post OP: } 20\end{array}$ & 0.0 & 40.0 & 40.0 & 230 \\
\hline 8 & $F=14$ & 42521 & $10 / 24 / 2007$ & 10/30/2007 & 5 Years & 2 Years & $\begin{array}{l}\text { Large \& } \\
\text { Bilateral }\end{array}$ & Leff Ear & Left Esr & Abromal & Polypoidal & Good & 1.7 & $\begin{array}{l}\text { Pre of: } 20 \\
\text { Post op:20 }\end{array}$ & 0.0 & 43.3 & 41.6 & $>30$ \\
\hline 9 & F-32 & 42252 & $10 / 222 / 2007$ & 10/30/2007 & 10 Years & 5 Years & Small & Right Esr & Right Ear & Abnomal & Nomal & Good & 6.7 & $\begin{array}{l}\text { pre of: } 20 \\
\text { Post op: } 10\end{array}$ & 10.0 & 33.3 & 26.6 & $<30$ \\
\hline 10 & F-20 & 42235 & $10 / 2222007$ & $111 / 1 / 2007$ & 3 Years & 3 Years & Small & Right Ear & Right Ear & Normal & Normal & Good & 5.0 & $\begin{array}{l}\text { Pre of: } 20 \\
\text { post op: } 10\end{array}$ & 10.0 & 30.0 & 25.0 & $<30$ \\
\hline 11 & $F=-30$ & 43315 & 10/29/2007 & $11 / 1 / 2007$ & $11 \mathrm{yr}$ & $5 \mathrm{yr}$ & Large & left Ear & Left Ear & Abromal & Granulations & Failure & 0.0 & $\begin{array}{l}\text { Pre op:20 } \\
\text { Post OP :20 }\end{array}$ & 0.0 & 43.3 & 43.3 & 230 \\
\hline 12 & M-29 & 43676 & 10:30/2007 & $11 / 82007$ & $10 \mathrm{yr}$ & $5 y \mathrm{r}$ & Large & Right Ear & Right Ear & Abromal & Granulations & Fallure & 0.0 & $\begin{array}{l}\text { Pre op: } 20 \\
\text { Post of } 20\end{array}$ & 0.0 & 50.0 & 50.0 & $>30$ \\
\hline 13 & $\mathrm{~F}-45$ & 43679 & 10/31/2007 & $11 / 82007$ & $3 y \mathrm{r}$ & lyr & Large & Leff Ear & Left Ear & Nomal & Granulations & cood & 8.4 & $\begin{array}{l}\text { Pre OP: }: 20 \\
\text { Post OP :10 }\end{array}$ & 10.0 & 40.0 & 31.6 & $>30$ \\
\hline 14 & $\mathrm{~F}-40$ & 43323 & 10/31/2007 & $11 / 6 / 2007$ & $10 y x$ & $5 \mathrm{yr}$ & Large & Right Ear & Right Eor & Abnomal & Granulations & Failure & 0.0 & $\begin{array}{l}\text { Pre op: } 20 \\
\text { Post OP:20 }\end{array}$ & 0.0 & 46.6 & 46.6 & $>30$ \\
\hline 15 & $F-20$ & 43730 & 10/31/2007 & $11 / 62007$ & $5 y \mathrm{r}$ & $2 \mathrm{yr}$ & Large & Left Ear & Left Ear & Abromal & Polypoidal & Good & 5.0 & $\begin{array}{l}\text { Pre OP:20 } \\
\text { Post OP }: 10\end{array}$ & 10.0 & 40.0 & 35.0 & $>30$ \\
\hline 16 & F-15 & 43322 & 10:20/2007 & $11 / 8 / 2007$ & $7 \mathrm{yr}$ & $2 \mathrm{yr}$ & $\begin{array}{l}\text { Lorge \& } \\
\text { Bilateral }\end{array}$ & Right Ear & Right Ear & Abromal & $\begin{array}{c}\text { Tympanos } \\
\text { cleosis }\end{array}$ & Fallure & 0.0 & $\begin{array}{l}\text { Pre OP:20 } \\
\text { Post OP: } 20 \\
\end{array}$ & 0.0 & 43.3 & 43.3 & 230 \\
\hline 17 & $F-25$ & 44358 & $11 / 5 / 2007$ & $11 / 62007$ & $1 y \mathrm{r}$ & $1 y \mathrm{r}$ & Small & Leff Ear & Leff Esr & Nommal & Normal & Good & 8.4 & $\begin{array}{l}\text { Pre oP: } 20 \\
\text { Post OP: } 10\end{array}$ & 10.0 & 30.0 & 21.6 & $<30$ \\
\hline 18 & $M-30$ & 44368 & $11 / 5 / 2007$ & $11 / 6 / 2007$ & $1 \mathrm{Y}_{\mathrm{f}}$ & $1 \mathrm{Yr}_{\mathrm{r}}$ & Small & Right Ear & Right Ear & Normal & Nomal & Good & 8.4 & $\begin{array}{l}\text { Pre OP:10 } \\
\text { Post OP:05 }\end{array}$ & 5.0 & 35.0 & 26.6 & $<30$ \\
\hline 19 & $\mathrm{M}-23$ & 45369 & $11 / 122007$ & $11 / 13 / 2007$ & $10 \mathrm{Yr}$ & $10 \mathrm{Yr}_{\mathrm{r}}$ & Large & Right Ear & Right Ear & Abromal & Polypoidal & Good & 8.3 & $\begin{array}{l}\text { Pre op: } 20 \\
\text { Post OP:10 }\end{array}$ & 10.0 & 36.6 & 28.3 & $<30$ \\
\hline 20 & $M-30$ & 45683 & $11 / 144 / 2007$ & $11 / 115 / 2007$ & $3 \mathrm{Yr}$ & $1 \mathrm{Yr}$ & Small & Right Ear & Right Ear & Abnormal & Polypoidal & Good & 8.4 & $\begin{array}{l}\text { Pre OP:20 } \\
\text { Post OP:10 }\end{array}$ & 10.0 & 45.0 & 36.6 & $>30$ \\
\hline 21 & $F-27$ & 47780 & 11/28/2007 & $11 / 29 / 2007$ & $1 \mathrm{yr}$ & $1 \mathrm{yr}$ & Small & Left Ear & Left Ear & Abnormal & Normal & Good & 8.3 & $\begin{array}{l}\text { Pre OP: } 20 \\
\text { Post OP:10 }\end{array}$ & 10.0 & 43.3 & 35.0 & $>30$ \\
\hline 22 & $F-45$ & 47727 & $12 / 3 / 2007$ & 12/6/2007 & $15 \mathrm{Yr}$ & $5 \mathrm{Yr}$ & Large & Right Ear & Right Ear & Abnormal & $\begin{array}{c}\text { Tympanos } \\
\text { clerosis }\end{array}$ & Failure & 0.0 & $\begin{array}{l}\text { Pre OP:20 } \\
\text { Post OP:20 } \\
\end{array}$ & 0.0 & 53.3 & 53.3 & $>30$ \\
\hline 23 & $M-23$ & 48472 & 12/3/2007 & 12/6/2007 & $10 \mathrm{yr}$ & $5 \mathrm{yr}$ & Large & Left Ear & Left Ear & Abnormal & Polypoidal & Good & 8.4 & $\begin{array}{l}\text { Pre OP:20 } \\
\text { Post OP: } 10 \\
\end{array}$ & 10.0 & 45.0 & 36.6 & $>30$ \\
\hline 24 & $M-28$ & 72376 & $12 / 10 / 2007$ & $12 / 11 / 2007$ & $6 \mathrm{yr}$ & $2 \mathrm{yr}$ & Large & Right Ear & Right Ear & Norms1 & Normal & Good & 10.0 & $\begin{array}{l}\text { Pre OP:40 } \\
\text { Post OP: } 30\end{array}$ & 10.0 & 60.0 & 50.0 & $>30$ \\
\hline 25 & $F-17$ & 6437 & $12 / 10 / 2007$ & $12 / 11 / 2007$ & $3 \mathrm{Yr}$ & $1 \mathrm{Yr}$ & Small & Right Ear & Right Ear & Normal & Normal & Good & 8.3 & $\begin{array}{l}\text { Pre OP:10 } \\
\text { Post OP:05 }\end{array}$ & 5.0 & 43.3 & 35.0 & $>30$ \\
\hline 26 & $F-27$ & 49494 & $12 / 10 / 2007$ & $12 / 11 / 2007$ & $5 y r$ & $1 \mathrm{Yr}$ & Small & Right Ear & Right Ear & Abnormal & Normal & Good & 10.0 & $\begin{array}{l}\text { Pre OP:25 } \\
\text { Post OP:10 }\end{array}$ & 15.0 & 43.3 & 33.3 & $>30$ \\
\hline 27 & $F-34$ & 48777 & 12/5/2007 & 12/6/2007 & $7 \mathrm{yr}$ & $1 \mathrm{yr}$ & Small & Left Esr & Left Esr & Abnormal & Normal & Good & 11.7 & $\begin{array}{l}\text { Pre OP:20 } \\
\text { Post OP:10 } \\
\end{array}$ & 10.0 & 48.3 & 36.6 & $>30$ \\
\hline 28 & $F-22$ & 49776 & $12 / 12 / 2007$ & $12 / 13 / 2007$ & $5 \mathrm{Yr}$ & $3 \mathrm{Yr}$ & Small & Left Ear & Left Ear & Abnormal & Normal & Good & 6.7 & $\begin{array}{l}\text { Pre OP:15Post } \\
\text { OP:05 }\end{array}$ & 10.0 & 38.3 & 31.6 & $>30$ \\
\hline 29 & $F-30$ & 49784 & $12 / 12 / 2007$ & 1/22/2008 & $10 \mathrm{Yr}$ & $2 \mathrm{Yr}$ & Large & Right Ear & Right Egr & Normal & Normal & Good & 6.7 & $\begin{array}{l}\text { Pre OP:20 } \\
\text { Post OP:15 }\end{array}$ & 5.0 & 63.3 & 56.6 & $>30$ \\
\hline 30 & $F-31$ & 49785 & $12 / 12 / 2007$ & $12 / 20 / 2007$ & $10 \mathrm{Yr}$ & $5 \mathrm{Yr}$ & Large & Right Egr & Right Ear & Normal & Normal & Good & 6.7 & $\begin{array}{l}\text { Pre OP:20 } \\
\text { Post OP:10 }\end{array}$ & 10.0 & 53.3 & 46.6 & $>30$ \\
\hline 31 & $M-16$ & 59585 & $12 / 26 / 2007$ & $12 / 27 / 2007$ & $10 \mathrm{Yr}$ & $5 \mathrm{Yr}$ & Sms\|l & Right Ear & Right Ear & Abnormal & Polypoidsl & Failure & 0.0 & $\begin{array}{l}\text { Pre OP:10 } \\
\text { Post OP:10 }\end{array}$ & 0.0 & 23.3 & 23.3 & $<30$ \\
\hline 32 & M-35 & 2692 & $1 / 21 / 2008$ & 1/24/2008 & $5 \mathrm{Yr}$ & $2 \mathrm{Yr}$ & Small & Left Ear & Left Ear & Normal & Normal & Good & 6.6 & $\begin{array}{l}\text { Pre OP:20 } \\
\text { Post OP: } 10\end{array}$ & 10.0 & 36.6 & 30.0 & $>30$ \\
\hline 33 & $M-22$ & 50637 & $2 / 13 / 2007$ & $2 / 14 / 2007$ & $8 \mathrm{Yr}$ & $3 \mathrm{Yr}$ & Small & Left Ear & Left Ear & Normal & Normal & Good & 10.0 & $\begin{array}{l}\text { Pre OP:20 } \\
\text { Post OP:10 } \\
\end{array}$ & 10.0 & 33.3 & 23.3 & $<30$ \\
\hline 34 & $F \cdot 30$ & 52234 & $12 / 31 / 2007$ & 1/2/2008 & $10 \mathrm{Yr}$ & $5 \mathrm{Yr}$ & Small & Right Ear & Right Ear & Abnormal & Polypoidal & 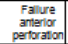 & 0.0 & $\mathrm{NiI}$ & NiI & 35.0 & 35.0 & $>30$ \\
\hline 35 & $F \cdot 38$ & 52342 & 1/1/2008 & 1/2/2008 & $15 \mathrm{Yr}$ & $5 \mathrm{Yr}$ & Large & Right Ear & Right Ear & Abnormal & Polypoids! & $\begin{array}{c}\begin{array}{c}\text { Failure } \\
\text { anterior } \\
\text { dehiserer } \\
\text { oe }\end{array} \\
\end{array}$ & 11.7 & $\begin{array}{l}\text { Pre OP:20 } \\
\text { Post OP:20 }\end{array}$ & 0.0 & 78.3 & 66.6 & $>30$ \\
\hline 36 & $F-33$ & 14684 & $4 / 21 / 2008$ & $4 / 22 / 2008$ & $10 \mathrm{Yr}$ & $5 \mathrm{Yr}$ & Small & Right Ear & Right Ear & Normal & Polypoidal & Good & 0.0 & $\begin{array}{l}\text { Pre OP:30 } \\
\text { Post OP: } 15 \\
\end{array}$ & 15.0 & 76.6 & 76.6 & $>30$ \\
\hline 37 & M.55 & 3756 & $1 / 30 / 2008$ & 1/31/2008 & $10 \mathrm{Yr}$ & $5 \mathrm{Yr}$ & Small & Right Ear & Right Esr & Norms I & Normal & Good & 6.7 & $\begin{array}{l}\text { Pre OP:20 } \\
\text { Post OP:10 }\end{array}$ & 10.0 & 35.0 & 28.3 & $<30$ \\
\hline 38 & M-25 & 18268 & $5 / 7 / 2008$ & $5 / 8 / 2008$ & $5 \mathrm{Yr}$ & $4 \mathrm{Yr}$ & Large & Left Ear & Left Ear & Norms! & Normal & Good & 8.3 & $\begin{array}{l}\text { Pre OP:20 } \\
\text { Post OP: } 10\end{array}$ & 10.0 & 43.3 & 35.0 & $>30$ \\
\hline
\end{tabular}




\begin{tabular}{|c|c|c|c|c|c|c|c|c|c|c|c|c|c|c|c|c|c|c|}
\hline 39 & $M-23$ & 18369 & $5 / 7 / 2008$ & $5 / 8 / 2008$ & $10 \mathrm{Yr}$ & $5 \mathrm{Yr}$ & Small & Left Esr & Left Ear & Abnormal & Polypoidal & $\begin{array}{c}\text { Failure } \\
\text { sterior } \\
\text { dehiscer } \\
\text { oe }\end{array}$ & 0.0 & $\begin{array}{l}\text { Pre OP: } 10 \\
\text { Post OP:10 }\end{array}$ & 0.0 & 25.0 & 25.0 & $<30$ \\
\hline 40 & $M-20$ & 9694 & $3 / 17 / 2008$ & $3 / 18 / 2008$ & $7 \mathrm{Yr}$ & $3 \mathrm{Yr}$ & Small & Right Ear & Right Esr & Normsl & Normal & Good & 6.6 & $\begin{array}{l}\text { Pre OP:20 } \\
\text { Post OP:10 }\end{array}$ & 10.0 & 36.6 & 30.0 & 30 \\
\hline 41 & $F-45$ & 9928 & $5 / 7 / 2008$ & $5 / 8 / 2008$ & $10 \mathrm{Yr}$ & $5 \mathrm{Yr}$ & Small & Left Ear & Left Ear & Normal & Normal & Good & 1.7 & $\begin{array}{l}\text { Pre OP:10 } \\
\text { Post OP:05 }\end{array}$ & 5.0 & 38.3 & 36.6 & $>30$ \\
\hline 42 & F-19 & 16942 & 4/30/2008 & $5 / 1 / 2008$ & $5 \mathrm{Yr}$ & $2 \mathrm{Yr}$ & Small & Right Ear & Right Ear & Abnormal & Normal & Good & 8.3 & $\begin{array}{l}\text { Pre OP:20 } \\
\text { Post OP:05 }\end{array}$ & 15.0 & 31.6 & 23.3 & $<30$ \\
\hline 43 & $F-36$ & 7716 & $3 / 3 / 2008$ & $3 / 4 / 2008$ & $8 \mathrm{Yr}$ & $2 \mathrm{Yr}$ & Small & Left Ear & Left Egr & Normal & Normal & Good & 8.4 & $\begin{array}{l}\text { Pre oP:20 } \\
\text { Post OP:10 }\end{array}$ & 10.0 & 45.0 & 36.6 & $>30$ \\
\hline 44 & M-20 & 23545 & 6/11/2008 & 6/12/2008 & $6 \mathrm{Yr}$ & $1 \mathrm{Yr}$ & Large & Left Ear & Left Ear & Abnormal & Granulations & Failure & 11.7 & $\begin{array}{l}\text { Pre OP:20 } \\
\text { Post OP:10 }\end{array}$ & 10.0 & 45.0 & 33.3 & $>30$ \\
\hline 45 & M-19 & 13639 & 4/16/2008 & 4/17/2008 & $10 \mathrm{Yr}$ & $5 \mathrm{Yr}$ & Small & Right Ear & Right Egr & Normal & Normal & Good & 10.0 & $\begin{array}{l}\text { Pre oP:25 } \\
\text { Post OP:10 }\end{array}$ & 15.0 & 33.3 & 23.3 & $<30$ \\
\hline 46 & $F-25$ & 3517 & $1 / 26 / 2008$ & 1/28/2008 & $10 \mathrm{Yr}$ & $7 \mathrm{Yr}$ & Small & Right Ear & Right Ear & Normal & Normsl & Good & 16.1 & $\begin{array}{l}\text { Pre OP:25 } \\
\text { Post OP:10 }\end{array}$ & 15.0 & 48.3 & 31.6 & $>30$ \\
\hline 47 & $M-20$ & 21172 & $5 / 26 / 2008$ & 6/3/2008 & $14 \mathrm{Yr}$ & $10 \mathrm{Yr}$ & $\begin{array}{l}\text { Large \& } \\
\text { Bilsteral }\end{array}$ & Left Ear & Left Ear & Abnormal & Normal & Good & 3.4 & $\begin{array}{l}\text { Pre OP: } 10 \\
\text { Post OP:05 }\end{array}$ & 5.0 & 35.0 & 31.6 & $>30$ \\
\hline 48 & $F-26$ & 23523 & 6/11/2008 & 6/12/2008 & $20 \mathrm{Yr}$ & $7 \mathrm{Yr}$ & $\begin{array}{l}\text { Large \& } \\
\text { Bisteral }\end{array}$ & Left Ear & Left Ear & Normal & Polypoidal & Good & 10.0 & $\begin{array}{l}\text { Pre OP:20 } \\
\text { Post OP: } 10\end{array}$ & 10.0 & 38.3 & 28.3 & $<30$ \\
\hline 49 & $M-20$ & 24656 & 6/19/2008 & 6/20/2008 & $15 \mathrm{Yr}$ & $5 \mathrm{Yr}$ & Large & Left Esr & Left Ear & Normal & Polypoidal & Good & 8.3 & $\begin{array}{l}\text { Pre OP:10 } \\
\text { Post OP:05 }\end{array}$ & 5.0 & 28.3 & 20.0 & $<30$ \\
\hline 50 & F-18 & 16310 & 4/24/2008 & $5 / 2 / 2008$ & $7 \mathrm{Yr}$ & $6 \mathrm{Yr}$ & Small & Left Ear & Left Ear & Normal & Normal & Good & 8.4 & $\begin{array}{l}\text { Pre OP:25 } \\
\text { Post OP: } 10\end{array}$ & 15.0 & 30.0 & 21.6 & $<30$ \\
\hline
\end{tabular}

TABLE No. 2: ANALYSIS OF THESIS RESULTS - GOVT GENERAL HOSPITAL KMC, KURNOOL, DEPT.OF ENT

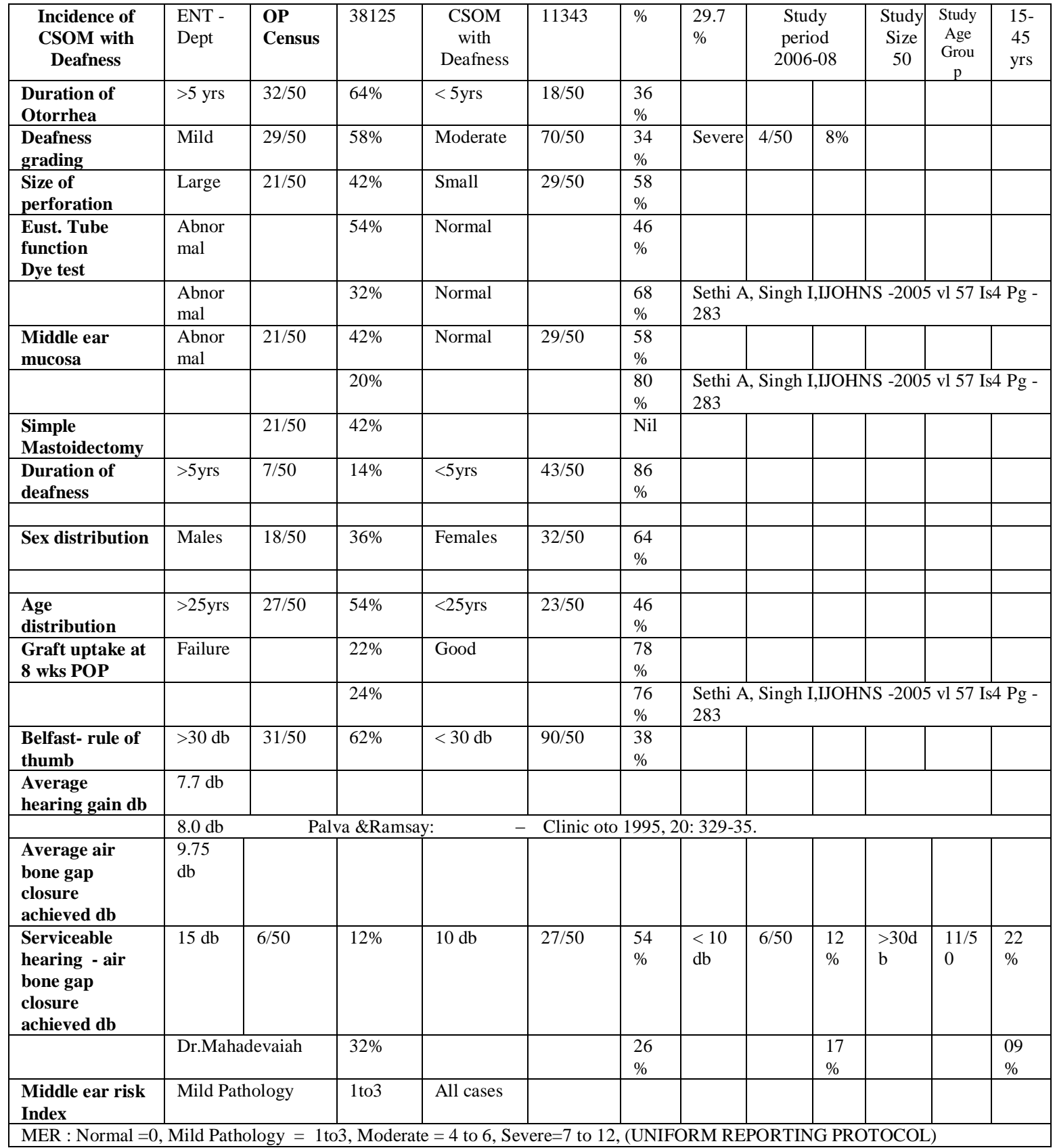

